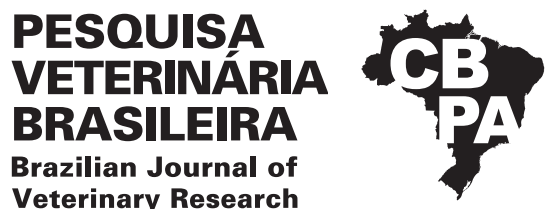

Pesq. Vet. Bras. 41:e06903, 2021

DOI: 10.1590/1678-5150-PVB-6903

Original Article

Livestock Diseases

ISSN 0100-736X (Print)

(cc) BY-NC

ISSN 1678-5150 (Online)

\title{
Molecular characterization of goose parvovirus in geese of Turkey ${ }^{1}$
}

\author{
Oya Bulut ${ }^{2}$ (D) Irmak Dik $^{2}$ (D), Hatice P. Aslim²* (D), Cagri Avci ${ }^{3}$ (D), Hasan S. \\ Palanci $^{2}$ (D) Sezer Akbaba ${ }^{4}$ (D), Varol Çivril ${ }^{2}$ (D) and Hasan H. Hadimli ${ }^{5}$ (C)
}

\begin{abstract}
Bulut O., Dik I., Aslim H.P., Avci C., Palanci H.S., Akbaba S., Çivril V. \& Hadimli H.H. 2021. Molecular characterization of goose parvovirus in geese of Turkey. Pesquisa Veterinária Brasileira 41:e06903, 2021. Department of Virology, Veterinary Faculty, Selçuk University, Konya, Turkey. E-mail: hpelinucan@gmail.com

Goose parvovirus (GPV), also called Derzsy's disease, is a viral pathogen that causes high morbidity and mortality in goslings and ducklings. In this study, we perform the molecular characterization of the GPV in Turkey. The definition of similarity to the world of GPV isolates in Turkey and construction of a phylogenetic tree was aimed. For this purpose, the presence of GPV in the liver, spleen, and intestine tissues of nine goslings with symptoms such as dysphagia, bilateral ocular swelling, eye discharge, diarrhea, and fatigue were investigated by real-time PCR method and all samples were detected as positive. According to the data obtained by molecular characterization, phylogenetic analysis of GPV has been presented in Turkey. As a result of this study, it was determined that the GPVs available in Turkey are virulent strains.
\end{abstract}

INDEX TERMS: Goose parvovirus, real-time pcr, phylogenetic analysis, Turkey, geese.

\begin{abstract}
RESUMO.- [Caracterização molecular de parvovírus de ganso em gansos da Turquia.] 0 parvovírus do ganso (GPV), também chamado de doença de Derzsy, é um patógeno viral que causa alta morbidade e mortalidade em gansos e patinhos. Neste estudo, objetivou-se a determinação da caracterização molecular do GPV na Turquia, a definição da similaridade com o mundo dos isolados de GPV na Turquia e a construção de uma árvore filogenética. Para tanto, a presença de GPV no fígado, baço e tecidos do intestino de nove gansos com sintomas como disfagia, edema ocular bilateral, secreção ocular, diarreia e fadiga foram investigados pelo método de PCR em tempo real e todas as amostras foram detectadas tão positivo. À luz dos dados obtidos por caracterização molecular, a análise filogenética do GPV foi apresentada na Turquia. Como resultado deste estudo, foi determinado que os GPVs disponíveis na Turquia são cepas virulentas.
\end{abstract}

TERMOS DE INDEXAÇÃO: Parvovírus de ganso, PCR em tempo real, análise filogenética, Turquia, gansos.

\footnotetext{
${ }^{1}$ Received on June 10, 2021.

Accepted for publication on July 6, 2021.

${ }^{2}$ Department of Virology, Veterinary Faculty, Selçuk University, Konya, Turkey. *Corresponding author: hpelinucan@gmail.com

${ }^{3}$ Department of Virology, Veterinary Faculty, Cukurova University, Adana, Turkey.

${ }^{4}$ Department of Virology, Veterinary Control and Research Institute, Konya, Turkey.

${ }^{5}$ Department of Microbiyology, Veterinary Faculty, Selçuk University, Konya, Turkey.
}

\section{INTRODUCTION}

Goose parvovirus (GPV) infections, also known as Derzsy's disease (DD), are an important viral infection with high mortality in goslings (Takehara et al. 1995). It has been taxonomically classified in the Dependoparvovirus genus of the Parvoviridae family (Yu et al. 2016, Cotmore et al. 2019). GPV has a single-stranded DNA structure and is a non-enveloped virus (Liu et al. 2017). The GPV genome is about 5.1-kb long and contains two open reading frames (ORFs). Left ORF-1 encodes non-structural proteins involved in viral replication. ORF-2 on the right encodes the capsid proteins VP1, VP2, VP3. VP2 and VP3 contain the same C-terminal as VP1 (CH ve ark 2015). In waterfowl, two genetically associated parvovirus subgroups have been identified, named GPV and Muscovy duck parvovirus (MDPV). GPV primarily infects geese and Muscovy ducks. MDPV only infects Muscovy ducks and some cross-breed duck species. The overall protein sequences of these two agents have approximately $85 \%$ similarity. They are antigenically related to each other; however, the crossprotection ability of the antibodies they produce is very limited. GPV and MDPV are excessively shed via feces of infected waterfowl. Therefore, they spread quickly to susceptible birds, both directly and indirectly, causing large-scale fatal outbreaks in regional goose and duck farms (Yu et al. 2016).

The host range of Goose parvovirus is very limited. Its natural hosts are geese and Muscovy ducks (Cairina moschata). The clinical findings of infected animals include drowsiness, 
ataxia, weight loss, palpebral swelling, dysphagia, and anorexia. Characteristic lesions in infected offspring are ascites, hydropericardium, enteritis, myocardium, and degenerative, inflammatory changes in the liver. It has been reported that GPV infections are observed in countries where goose production is common in the world (Jansson et al. 2007, Wan et al. 2016, Liu et al. 2017). Although vaccination programs against GPV have been developed in the last 30 years, its epidemiological existence continues (Tarasiuk et al. 2019).

The agent can be detected by virus isolation (VI) from goose or duck embryos, polymerase chain reaction (PCR), agar gel precipitation test, electron microscopy (Ning et al. 2018), LAMP (Loop-Mediated Isothermal Amplification) ELISA, serum neutralization test (Woźniakowski et al. 2012), immunofluorescent test (IFA), Western blot (Tarasiuk et al. 2019). A real-time PCR test has many advantages over serological diagnostic methods and molecular methods such as agar gel diffusion, immunohistochemistry, ELISA in the diagnosis of GPV (Yu et al. 2016).

VP3 a highly protected region of the GPV gene is very suitable for diagnosis by PCR (Yang et al. 2009).

This study aimed to determine the molecular characterization of GPV, which is an important viral disease for geese and ducks, in Turkey, and to reveal the similarities of the obtained isolates with GPV isolates and vaccine strains in the world, creating a phylogenetic tree.

\section{MATERIALS AND METHODS}

In this study, intestine, spleen and liver tissues of nine goslings obtained from the project named "Virological Investigation of Parvovirus Infections in Geese" were used. The supernatants obtained after the homogenization and centrifugation processes of the organs were performed, stored at $-20^{\circ} \mathrm{C}$ until they were used in the PCR procedure. Then, the presence of the GPV factor was tested with the real-time PCR method. Conventional PCR procedure was applied to positive samples. Gene sequence analysis was performed from the obtained PCR products and the results were evaluated.

Table 1. Real-time PCR primers used in the study

\begin{tabular}{cccc}
\hline Name & Sequence 5' to 3' & Position & $\begin{array}{c}\text { Amplicon } \\
\text { size (bp) }\end{array}$ \\
\hline GPV-F & GTGCCGATGGAGTGGGTAAT & $3084-$ & 60 \\
& & 3103 & \\
GPV-R & ACTGTGTTTCCCATCCATTGG & $3122-$ & \\
& & 3143 & \\
GPV-FP & 6FAM-FTCGCAATGCCAATTTCCCGAGGP- & $3098-$ & \\
& TAMRA & 3120
\end{tabular}

Table 2. Real-time PCR protocol

\begin{tabular}{lc}
\hline \multicolumn{1}{c}{ Reagent } & Volume \\
\hline LightCycler 480 Probes Master $2 \times$ Conc & $10 \mu \mathrm{l}$ \\
Primer forward $(10 \mathrm{pmol} / \mu \mathrm{l})$ & $0.8 \mu \mathrm{l}$ \\
Primer reverse $(10 \mathrm{pmol} / \mu \mathrm{l})$ & $0.8 \mu \mathrm{l}$ \\
Probe $(5 \mathrm{pmol} / \mu \mathrm{l})$ & $0.8 \mu \mathrm{l}$ \\
Distilled water & $2.6 \mu \mathrm{l}$ \\
Template DNA & $5 \mu \mathrm{l}$ \\
Volume collected & $20 \mu \mathrm{l}$
\end{tabular}

Extraction. Organ samples that were previously detected as GPV positive in the virology laboratory of the Veterinary faculty of Selçuk University were resolved. Supernatants obtained as a result of homogenization of organs were subjected to the extraction process. A commercial extraction kit (QIAGEN DNeasy Blood \& Tissue Kit 250 Cat. No. 69506) was used for this purpose. The procedure was carried out per the protocol specified by the manufacturer.

Real-time PCR. Real-time PCR procedure was performed using gene zone-specific primer/probe sets (Table 1) to determine the presence of GPV in the DNA obtained as a result of extraction. Analyzes were performed with Light Cyler 480 Probe Master Kit (Roche, USA) by modifying the manufacturer's protocol. The real-time PCR protocol and thermal cycle program to be applied for each PCR reaction are given in Table 2 and Table 3. Vaccine Hoekstra strain (Palmivax L477565 Boehringer Ingelheim) was used as positive control and RNA free water was used as the negative control.

Conventional PCR, Sequence analysis of PCR product. The PCR procedure was performed using primer pairs specific to the VP3 gene (GPV F 5'-CCGGATCCATGGCAGAGGGAGGAGGC-3' and GPV R 5'-GCGCTCGAGTTACAGATT TTGAGTTAG3') in the samples determined positive by real-time PCR (Shao et al. 2015) (Table 4 and 5). As a result of the reaction, PCR products were transferred to $2 \%$ agarose gel and exposed to electrophoresis for 40 minutes. At the end of the procedure, the PCR products were examined on the gel imaging device and the samples giving a band of $1650 \mathrm{bp}$ were accepted as positive (Fig.1). Vaccine Hoekstra strain (Palmivax L477565 Boehringer Ingelheim) was used as positive control and RNA free water was used as the negative control.

The bidirectional sequence of the PCR products selected for sequence analysis was commercially obtained by service. The obtained data were searched for homology in GenBank using the

Table 3. Real-time PCR stages and temperature $\left({ }^{\circ} \mathrm{C}\right) /$ time values applied during these stages

\begin{tabular}{lcc}
\hline \multicolumn{1}{c}{ Stage } & Temperature/time & Cycle \\
\hline PCR baseline activation & $95^{\circ} \mathrm{C} / 10 \mathrm{~min}$. & $1 \mathrm{x}$ \\
Denaturation & $95^{\circ} \mathrm{C} / 10 \mathrm{sec}$. & $40 \mathrm{x}$ \\
Bonding/extending & $60^{\circ} \mathrm{C} / 30 \mathrm{sec}$. &
\end{tabular}

Table 4. Conventional PCR Protocol

\begin{tabular}{cc}
\hline Reagent & Volume \\
\hline dNTP $(10 \mathrm{mM})$ & $1 \mu \mathrm{l}$ \\
MgCL $(25 \mathrm{mM})$ & $2.5 \mu \mathrm{l}$ \\
Reverse Primer & $2 \mu \mathrm{l}$ \\
Forward Primer & $2 \mu \mathrm{l}$ \\
Taq Polymerase & $1.5 \mu \mathrm{l}$ \\
Distilled water & $36 \mu \mathrm{l}$ \\
DNA & $5 \mu \mathrm{l}$ \\
Volume collected & $50 \mu \mathrm{l}$
\end{tabular}

Table 5. Conventional PCR stages and temperature $\left({ }^{\circ} \mathrm{C}\right) /$ time values applied during these stages

\begin{tabular}{lcc}
\hline \multicolumn{1}{c}{ Stage } & Temperature/time & Cycle \\
\hline PCR baseline activation & $95^{\circ} \mathrm{C} / 5 \mathrm{~min}$. & $1 \mathrm{x}$ \\
Denaturation & $94^{\circ} \mathrm{C} / 1 \mathrm{~min}$. & $30 \mathrm{x}$ \\
Bonding & $52^{\circ} \mathrm{C} / 1 \mathrm{~min}$. & \\
Extending & $72^{\circ} \mathrm{C} / 2 \mathrm{~min}$. &
\end{tabular}


BLAST program provided by NCBI. BLAST analysis was performed to detect similar zones of the registered samples showing sequential homology in the NCBI database.

Finch TV (Geospiza, Seattle/WA) program was used to control the chromatogram files of the bidirectional sequences of the isolate No. GPV/TR42/01. Bidirectional *.ab1 extension chromatogram files were visualized using Finch Tv (Geospiza, Seattle/WA) program. The bidirectional DNA sequences were aligned and combined in the AliView program, and the consensus/contig (common line sequence) sequence was obtained (Altschul et al. 1990).

To reveal the genetic relationship between the virus sequence obtained in this study and the virus sequences detected in previous studies, reference (isolate) sequences registered in the GenBank database were used. Data on reference GPV isolates are given in Table 6.

Sequence data were aligned with other viruses obtained from GenBank using Mafft (Katoh \& Standley 2013) software on AliView (Larsson 2014) interface. The phylogenetic tree was created through the Neighbor-Joining/Maximum Likelihood (Saitou \& Nei 1987) algorithm/method using MEGA X (Kumar et al. 2018). The phylogenetic tree was rooted using an outgroup sequence (FM strain MDPV, access number U22967).

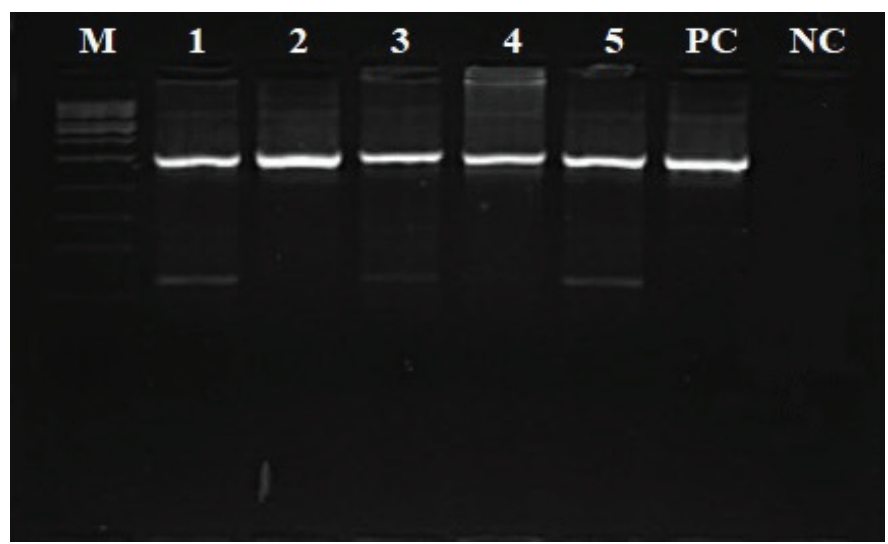

Fig.1. GPV Conventional PCR results. 1kp DNA marker (M), positive samples (1-5), GPV positive control (PC), negative control (NC).'
Ethical approval. All procedures and animal care complied with the guidelines of the Selçuk University Veterinary Faculty Ethics Committee (Ethical approval number 2019/66 on August 8, 2019).

\section{RESULTS}

With the current study, intestine, spleen, and liver tissues of nine goslings who had symptoms such as weight loss, dysphagia, bilateral ocular swelling and discharge, diarrhea, fatigue, and died were taken. Real-time PCR procedure (Table 2) was performed and all samples were determined as GPV positive (Fig.2). Then, the PCR procedure was applied for the sequence (Table 4 and 5). When the sequence data were evaluated, it was determined that all samples had the same nucleotide sequence, so a single isolate (GPV/TR42/01) was included in the phylogenetic tree (Fig.3). The changes in the amino acid position of the obtained isolate compared with the reference strain were submitted in Table 7.

Phylogenetic analyzes show that GPV/TR42/01 is closely related to the international standard virulent strain GPV-B (GenBank U25749).

In the protein analysis, it was determined that the $\mathrm{N}$ (Asparagine) amino acid at position 301 of the GPV VP3 gene was highly conserved in other strains on GenBank, but the $\mathrm{S}$ amino acid due to mutation was found at position 301 of GPV/TR42/01. In addition to these, A326G, L339I, K377R and D505N changes were detected (Table 8).

Attanue strains are reported to encode remarkably different amino acids from virulent strains at positions 266, 287, 381, 382, 390 and 395 of the VP3 protein (Yan et al. 2019). When the amino acid motifs at positions 266, 287, 381, 382, 390 and 395 of the GPV/TR42/01 strain were examined, it was determined that it differed from the attanuated strains and showed high similarity with the virulent strains.

\section{DISCUSSION AND CONCLUSION}

Since 1956, GPV has been widely observed in Europe, Asia, America, and China (Shien et al. 2008). GPV is a fatal infection for goslings and ducklings with serious economic losses (Yu et

Table 6. Data on GPV isolates in GenBank and obtained from different countries

\begin{tabular}{|c|c|c|c|c|c|}
\hline GenBank access number & Name of strain & Location/country & Host & Date & Source or reference \\
\hline MT919292 & GPV/TR42/01 & Turkey & Goose & 2020 & This study \\
\hline EU088102 & DB3 strain (Comp genome) & China & Goose & 2007 & GenBank \\
\hline U25749 & Virulent B & Hungary & Anser anser & 1995 & GenBank \\
\hline EU583392 & VG32/1 & Germany & Goose & 2008 & GenBank \\
\hline EU583391 & 06-0329 & Taiwan & Goose & 2006 & GenBank \\
\hline KC178571 & Y & Anhui/China & Muscovy duck & 2011 & GenBank \\
\hline KC184133 & $\mathrm{E}$ & China & Goose & 2012 & GenBank \\
\hline EU583390 & $82-0321$ & China & Goose & 1982 & GenBank \\
\hline JF333590 & $\mathrm{SH}$ & Shanghai/China & Anser anser & 2009 & GenBank \\
\hline KC478066 & SHFX1201 & China & Swan & 2013 & GenBank \\
\hline
\end{tabular}


al. 2012). A few studies (Isidan et al. 2021, Kardoğan et al. 2021) are reporting the genetic characteristics of GPV in Turkey so far. In this study, the VP3 protein, which is the main component of the capsid on the surface of virus particles, was preferred for diagnosis. VP3 is an important protein since it is effective in the formation of neutralizing antibodies (Shao et al. 2015).

All samples were determined to be positive as a result of RT-PCR performed from tissue samples taken from nine goslings that died with clinical symptoms such as weight loss, dysphagia, bilateral ocular swelling and discharge, diarrhea, and fatigue. The sequences obtained as a result of the phylogenetic analysis and the amino acid sequences of 8 GPV VP3 genes were compared. The same mutations at the same position as the GPV-ZL and GPV-CH strains were determined. In the sequence of the VP3 gene of the GPV-CH and GPV-ZL strains, Ser, Ala, Lys, Glu, Asp and Lys are present respectively at the amino acids 266, 287, 390, 395, 381 and 382. These amino acids are given as Gly, Thr, Thr, Asp, Asn and Glu respectively

Table 7. VP3 gene amino acid sequence positions of the current isolate with the GPV reference strain

\begin{tabular}{lcccccc}
\hline & \multicolumn{5}{c}{ Amino acid positions of the VP3 gene } \\
\cline { 2 - 7 } & 266 & 287 & 381 & 382 & 390 & 395 \\
\hline EU088102 & Ser-S & Ala-A & Asp-D & Lys- & Lys- & Glu- \\
GPV/TR42/01 & & & & & & \\
GPV-ZL & Gly-G & Thr-T & Asn-N & Glu-E & Thr-T & Asp-D \\
GPV-CH & Ser-S & Ala-A & Asp-D & Lys- & Lys- & Glu- \\
GPV-PSH & Ser-S & Ala-A & Asp-D & Lys- & Lys- & Glu- \\
GPV-BCH & Gly & Thr & Asn & Glu & Thr & Asp \\
GPV-LY & Gly & Thr & Asn & Glu & Thr & Asp \\
GPV-JLJT & Gly & Thr & Asn & Glu & Thr & Asp \\
GPV-DH & Gly & Thr & Asn & Glu & Thr & Asp \\
GPV-B & Gly & Thr & Asn & Glu & Thr & Asp \\
& Gly & Thr & Asn & Glu & Thr & Asp
\end{tabular}

in the other six strains (Table 7). These common changes that occurred in GPV-CH and GPV-ZL suggest that they may cause GPV replication or a decrease in immune response in geese. Therefore, Gly, Thr, Asp, Asn and Glu, especially Gly and Thr, can be key amino acids of VP3. GPV-CH and GPV-ZL were determined to belong to the same branch when compared to the GPV-DB3 strain.

GPV-PSH, GPV-BCH, GPV-DH, GPV-LY and GPVJLJT are virulence strains, and GPV-ZL is an attenuated strain. The amino acid (aa) sequences of six GPV strains were compared to GPV-B and GPV-CH by the DNAMAN program. As a result, it was determined that the amino acid sequences of the attenuated strains (GPV-ZL and GPV-CH) shared common differences from the sequences of the virulent strains (the other six strains). Ser, Ala, Lys, Glu, Asp and Lys were present, respectively at amino acids $266,287,390,395,381$ and 382 of the VP3 sequence of GPV-ZL and GPV-CH. In the other six strains (GPV-PSH, GPVBCH, GPV-DH, GPV-B, GPV-LY and GPV-JLJT), these amino acids were Gly, Thr, Thr, Asp, Asn and Glu respectively. Virulent strains have more mutation zones than attenuated strains, because they are exposed to more environmental and geographic changes (Yan et al. 2019). Therefore, further studies investigating amino acids in the VP3 gene may display the key to the pathogenicity of GPV. When the 1531 bp VP3 partial sequence was compared or filtered with all similar sequences in the Genbank database, query cover over 99 , similarity rates were found between 81.14\% and 99.74\%. Also, Virulent B (U25749.1) with

Table 8. Amino acid changes of partial VP3 gene

\begin{tabular}{lccccc}
\hline & \multicolumn{5}{c}{ Position } \\
\cline { 2 - 6 } & 301 & 326 & 339 & 377 & 505 \\
\hline GPV/TR42/01 & S & G & I & R & N \\
Genbank data conserved amino acid & N & A & L & K & D
\end{tabular}

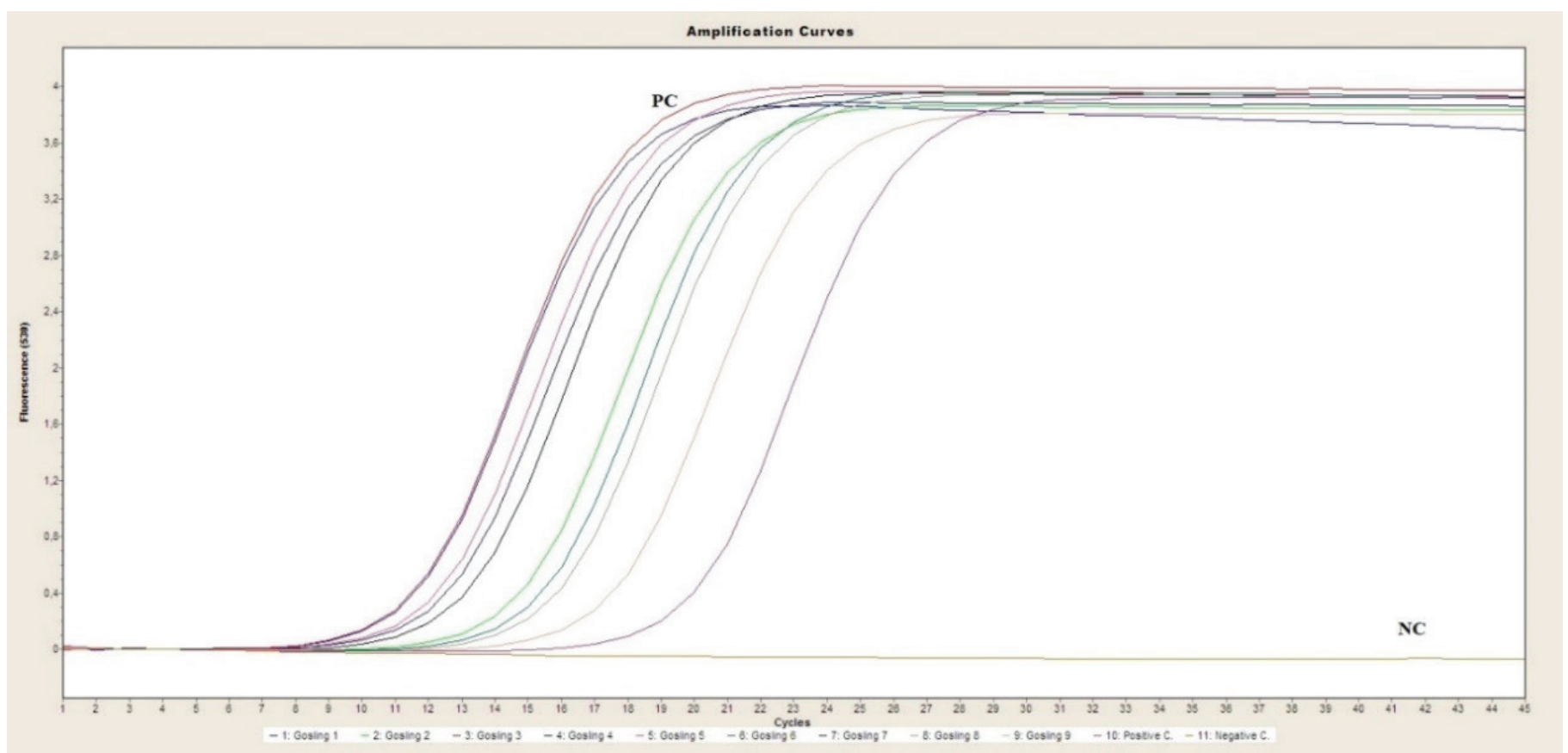

Fig.2. Real-time PCR result. Positive control (PC), negative control (NC). 


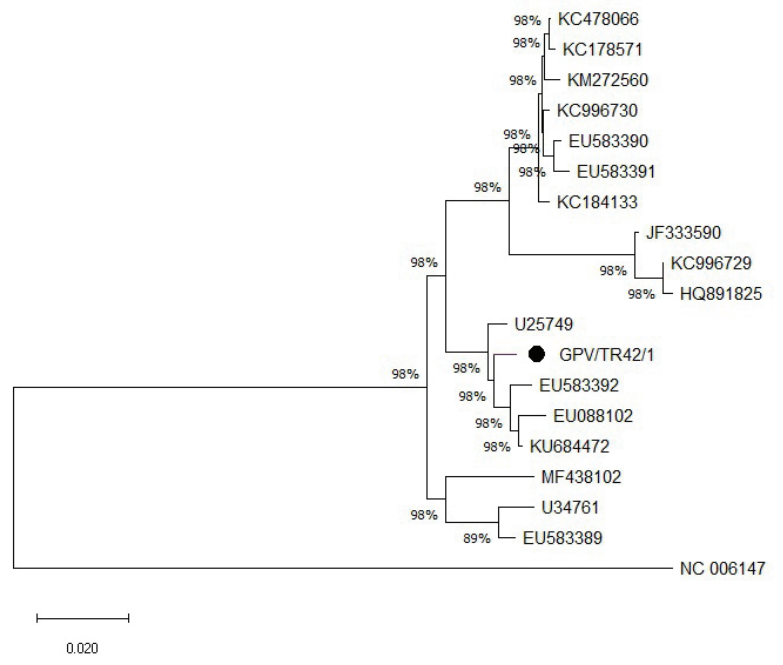

Fig.3. Phylogenetic analysis of the GPV part VP3 gene was created using the Neighbor-Joining method using the MEGAX program. The bootstrap value was chosen as 1000 .

Hungary 98.89\%, GPV GER (KU684472.1) with Germany 98.82\%, vaccine strain VG32/1 (EU583392.1) Taiwan with 98.69\% and DB3 (EU088102.1) China with a high similarity of 98.37\%. Additionally, Isidan et al. (2021) reported strains from Turkey: MW386079.1 Yozgat/19, MW386077.1 Çorum/19 and MW386078.1 Konya/19 have 99.74\%, 99.74\% and 99.61\% similarity rates, respectively.

The main countries where goose breeding is carried out in the world are China, Egypt, Ukraine, Romania, Poland, Madagascar, Hungary, and Russia. In Turkey, goose breeding has started to increase in recent years (Tilki \& Saatci 2016). With the increasing demand for the goose, GPV is regarded as the most common infection with high mortality in increasing goose farms. Due to the limited number of studies on GPV infection in Turkey, determining the prevalence and molecular types of this infection is of great importance. As a result, this seems to be one of the first studies to determine the molecular characterization of GPV in Turkey. The data obtained revealed that the strains in Turkey are pathogenic. Further studies concerning other gene zones (Rep and VP1) will help to understand the epidemiology of the disease and how to control it.

Authors contributions.- The authors contributed equally to this work.

Acknowledgments.- This study was supported by SUPABK (20401062).

Conflict of interest statement.- The authors declared that there is no conflict of interest.

\section{REFERENCES}

Altschul S.F., Gish W. \& Miller W. 1990. Basic local alignment search tool. J. Mol. Biol. 215(3):403-410. <https://dx.doi.org/10.1016/S00222836(05)80360-2><PMid:2231712>

Cotmore S.F., Agbandje-McKenna M., Canuti M., Chiorini J.A., Eis-Hubinger A.-M., Hughes J., Mietzsch M., Modha S., Ogliastro M., Pénzes J.J., Pintel D.J., Qiu J., Soderlund-Venermo M., Tattersall P. \& Tijssen P. 2019. ICTV virus taxonomy profile: Parvoviridae. J. Gen. Virol. 100:367-368. <https://dx.doi. org/10.1099/jgv.0.001212><PMid:30672729>
Isidan H., Turan T., Atasoy M.O. \& Coskun A. 2021. Molecular analysis of goose parvovirus field strains from a Derzsy's disease outbreak reveals local European-associated variants. Arch. Virol. 166:1931-1942. <https:// dx.doi.org/10.1007/s00705-021-05086-y>

Jansson D.S., Feinstein R., Kardi V., Mato T. \& Palya V. 2007. Epidemiologic investigation of an outbreak of goose parvovirus infection in Sweden. Avian Dis. 51(2):609-613.<https://dx.doi.org/10.1637/0005-2086(2007)51[609:EI OAO0]2.0.CO;2><PMid:17626494>

Kardoğan Ö., Müştak H.K. \& Müştak İ.B. 2021. The first detection and characterization of goose parvovirus (GPV) in Turkey. Trop. Anim. Health Prod. 53:36. <https://dx.doi.org/10.1007/s11250-020-02463-8> $<$ PMid:33230580>

Katoh K. \& Standley D.M. 2013. MAFFT multiple sequence alignment software version 7: improvements in performance and usability. Mol. Biol. Evol. 30(4):772-780. <https://dx.doi.org/10.1093/molbev/mst010>

Kumar S., Stecher G., Li M., Knyaz C. \& Tamura K. 2018. MEGA X: molecular evolutionary genetics analysis across computing platforms. Mol. Biol. Evol. 35(6):1547-1549. <https://dx.doi.org/10.1093/molbev/msy096> $<$ PMid:29722887>

Larsson A. 2014. AliView: a fast and lightweight alignment viewer and editor for large datasets. Bioinformatics 30(22):3276-3278. <https://dx.doi. org/10.1093/bioinformatics/btu531><PMid:25095880>

Liu P., Zhang J., Chen S., Wang M. \& Cheng A. 2017. Genome sequence of a goose parvovirus strain isolated from an ill goose in China. Genome Announc. 5(17):e00227-17. <https://dx.doi.org/10.1128/genomeA.00227-17> $<$ PMid:28450508>

Ning K., Liang T., Wang M., Dong Y., Qu S. \& Zhang D. 2018. Pathogenicity of a variant goose parvovirus, from short beak and dwarfism syndrome of Pekin ducks, in goose embryos and goslings. Avian Pathol. 47(4):391-399. <https://dx.doi.org/10.1080/03079457.2018.1459040><PMid:29630396>

Saitou N. \& Nei M. 1987. The neighbor-joining method: a new method for reconstructing phylogenetic trees. Mol. Biol. Evol. 4(4):406-425. <https:// dx.doi.org/10.1093/oxfordjournals.molbev.a040454>

Shao H., Lv Y., Qin A.J., Qian K. \& Ye J.Q. 2015. Genetic diversity of VP3 of goose parvovirus isolated from Southeastern China during 2012-2013. Mol. Genet. Microbiol. Virol. 30(4):233-236. <https://dx.doi.org/10.3103/ S0891416815040102>

Shien J.-H., Wang Y.-S., Chen C.-H., Shieh H.K., Hu C.-C. \& Chang P.-C. 2008. Identification of sequence changes in live attenuated goose parvovirus vaccine strains developed in Asia and Europe. Avian Pathol. 37(5):499-505. <https://dx.doi.org/10.1080/03079450802356979><PMid:18798024>

Takehara K., Nishio T., Hayashi Y., Kanda J., Sasaki M., Abe N., Hiraizumi M., Saito S., Yamada T., Haritani M. \& Yoshimura M. 1995. An outbreak of goose parvovirus infection in Japan. J. Vet. Med. Sci. 57(4):777-779. <https:// dx.doi.org/10.1292/jvms.57.777> <PMid:8519919>

Tarasiuk K., Holec-Gąsior L., Ferra B. \& Rapak A. 2019. The development of an indirect ELISA for the detection of goose parvovirus antibodies using specific VP3 subunits as the coating antigen. BMC Vet. Res. 15:274 <https://dx.doi.org/10.1186/s12917-019-2027-1>

Tilki M. \& Saatci M. 2016. Geese breeding in the world and Turkey. Türkiye Klinikleri Dölerme ve Suni Tohumlama 2(1):27-34.

Wan C.-H., Huang Y., Shi S.-H., Fu G.-H., Cheng L.-F., Chen H.-M., Fu Q.-L., Chen C.-T. \& Hu K.-H. 2016. Complete genome sequence of goose parvovirus isolated from Anser cygnoides in China. Kafkas Univ. Vet. Fak. Derg. 22(1):155-158. <https://dx.doi.org/10.9775/kvfd.2015.14242>

Woźniakowski G., Samorek-Salamonowicz E. \& Kozdruń W. 2012. Quantitative analysis of waterfowl parvoviruses in geese and Muscovy ducks by real-time polymerase chain reaction: correlation between age, clinical symptoms, and DNA copy number of waterfowl parvoviruses. BMC Vet. Res. 8:29 <https://dx.doi.org/10.1186/1746-6148-8-29><PMid:22420608> 
Yan Y.-Q., He T.-Q., Li R., Zhang S.-Y.,Wang K., Yi S.-S., Niu J.-T., Dong H. \& Hu G.-X. 2019. Molecular characterization and comparative pathogenicity of goose parvovirus isolated from Jilin province, Northeast China. Avian Dis. 63(3):481-485. <https:// dx.doi.org/10.1637/aviandiseases-D-19-00075><PMid:31967432>

Yang J.-L., Cheng A.-C., Wang M.-S., Pan K.-C., Li M., Guo Y.-F., Li C.-F., Zhu D.-K. \& Chen X.-Y. 2009. Development of a fluorescent quantitative real-time polymerase chain reaction assay for the detection of goose parvovirus in vivo. Virol. J. 6:142.<https://dx.doi.org/10.1186/1743-422X-6-142><PMid:19754946>
Yu K., Ma X., Sheng Z., Qi L., Liu C., Wang D., Huang B., Li F. \& Song M. 2016. Identification of goose-origin parvovirus as a cause of newly emerging beak atrophy and dwarfism syndrome in ducklings. J. Clin. Microbiol. 54(8):19992007. <https://dx.doi.org/10.1128/JCM.03244-15><PMid:27194692>

Yu T.-F, Ma B., Gao M.-C. \& Wang J.-W. 2012. Localization of linear B-cell epitopes on goose parvovirus structural protein. Vet. Immunol. Immunopathol. 145(1/2):522-526. <https://dx.doi.org/10.1016/j.vetimm.2011.11.022> <PMid:22209204> 